\title{
Study on Water Resources Allocation for Kertajati, Jatitujuh, and Ligung Sub-Districts to Support the Development of West Java International Airport (BIJB) and Kertajati Aerocity Area
}

\author{
Yadi Suryadi ${ }^{2,3,}{ }^{*}$, Asrini Chrysanti ${ }^{1}$, Febya Nurnadiati $^{1}$, Mohammad Bagus Adityawan ${ }^{2,3}$, and Arno Adi Kuntoro ${ }^{2}$ \\ ${ }^{1}$ Graduate School of Civil Engineering, Institut Teknologi Bandung, Jalan Ganesha 10, Bandung 40132, Indonesia \\ ${ }^{2}$ Water Resources Engineering Research Group, Institut teknologi Bandung, Jalan Ganesha 10, Bandung 40132, Indonesia \\ ${ }^{3}$ Water Resources Development Center, Institut teknologi Bandung, Jalan Ganesha 10, Bandung 40132, Indonesia
}

\begin{abstract}
The Bandarudara Internasional Jawa Barat (BIJB) and Kertajati Aerocity are under construction and expected to be a center of economic activity supported by potential of natural resources and agriculture. They later will act as a driver of economic growth in West Java, especially for surrounding area such as Kertajati, Jatitujuh and Ligung Sub-districts. As an affect of the the development of BIJB and Kertajati Aerocity, the water demand of surrounding area will increase. Therefore an analysis of water demand and availability is needed. This research supports by analyzing the water balance, water demand, and also water allocation using WEAP (Water Evaluation and Planing) software tool. Water balance of Cimanuk-Tomo, Cimanuk-Monjot, and Cilutung-Dam Kamun river are analyzed, water demand of the three sub-districts are also projected and become the inputs of the water allocation model. The result of WEAP model simulation shows that the Cimanuk River can meet the water demand of the three sub-districts until 2040.
\end{abstract}

\section{Background}

PT Bandarudara Internasional Jawa Barat (PT BJIB) responsible for operating West Jawa Internasional Airport and developing Aerocity. In order to encourage the development of the Ciayumajakuning (CirebonIndramayu-Majalengka-Kuningan) region as well as the increase of economic growth and public service especially in the field of transportation, set in 2010 the development and growth of the international airport of West Java and Kertajati Aerocity. BJIB's accessibility is guaranted by having both highway and railway connected Bandung, Kertajati, dan Cirebon. BJIB plans to ensure sufficient capacity to meet future demand in air travel wich can handle 5 million passanger per year.

Development and growth of BIJB and Kertajati Aerocity is implemented by developing Kertajati Urban Area which is integrated with the development and growth of airport. The development of Kertajati Urban Area certainly affect Kertajati Area itself and also around. Among them is the Center for Local Activities Kertajati with service functions as a commercial area and services, an integrated industrial area BIJB, the development of maritime Aerocity, Central Services Area Jatitujuh with service functions as housing development, services, industry, and agriculture Serving sub-district or villagelevel activities, and Central Services Area Ligung with service function as security area, industrial development, social service, and agriculture serving sub district or some village. Therefore it is necessary to plan development and growth of three sub districts to support development and growth of BIJB and Kertajati Aerocity Regions.

Water demand increases along with population growth in Majalengka Regency and will continue to increase in line with the development and growth of BIJB and Kertajati Aerocity. Especially in the regions service areas in Kertajati Subdistrict (outside Region Aerocity), Jatitujuh, and Ligung. Therefore it is necessary to analyze the water demand and identify the water resources to meet the total water demand, as well as the planning of water resources management in 3 (three) sub districts to support the development and growth of BIJB and Kertajati Aerocity. With well managed water resources, water demand (domestic needs) can be fulfilled and sustainable water resources management can support infrastructure development and growth. This research using Water Evaluation and Planning (WEAP) system for water resources allocation, which is suitable for incorporates a demand priority and supply preference approach to drive the allocation of water from water supply. WEAP model using linear program algorithm, iterated to optimize demand and supply priorities. WEAP model has been used in several water related researches across the world, for example to determine the impact of a number of possible Development scenarios in Lake Tana Catchment, Ethiopia (Alemayehu et al. 2010) [7]. It is also used in Western Africa to study the impacts of hydropower production due to land use and land cover changer under climate changes (Obahoundje et al. 2017) [9].

\section{Location of the study area}

The BJIB and Kertajati Aerocity is located in Majalengka district, while the focus of this research are Kertajati, Jatitujuh and Ligung districts as shown in Figure 1. Majalengka is among the big districts such as Indramayu, Cirebon, Kuningan, Ciamis and Tasikmalaya. In urban

* Corresponding author: suryadi350@yahoo.com 
areas the water demand has been fulfilled from the Cimanuk River.

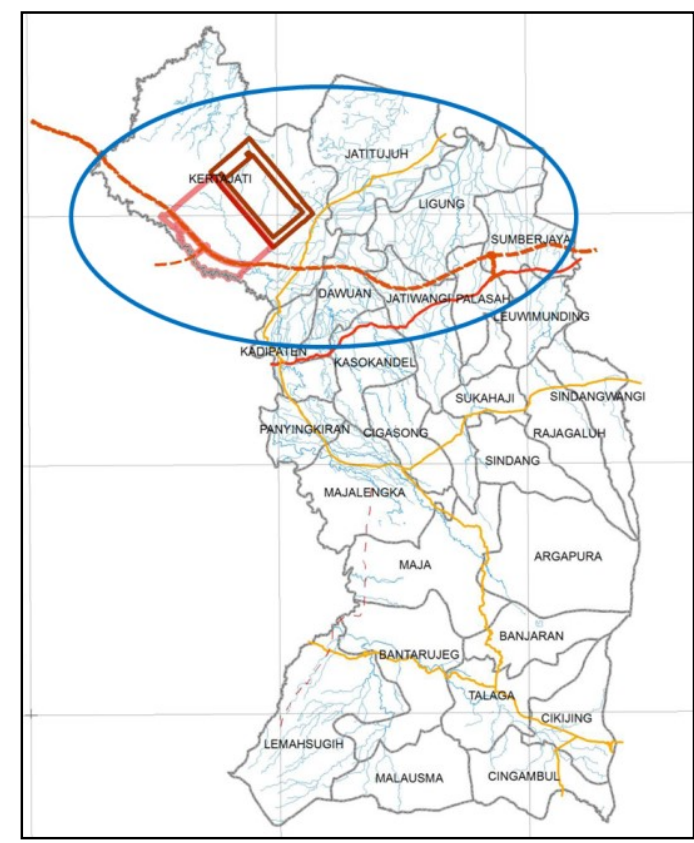

Fig. 1. Location of study area

\subsection{Hydroclimatology}

Majalengka and Kuningan districts are classified as wetlands with average annual rainfall ranges between $2000-4000 \mathrm{~mm}$. The wettest area of the region with annual average rainfall of $3500-4000 \mathrm{~mm}$ is in the northwest. Average annual rainfall in Majalengka regency ranges from 2,400 mm-3,800 mm per year with an average rainy day of 11 days per month. In 2010, Majalengka regency rained every month with the highest rainfall occurred in March 2010 which reached $586 \mathrm{~mm}$. During the period of 2008-2012, the annual rainfall in Majalengka was the lowest at 1,953 mm per year in 2009 and the highest at $3,459 \mathrm{~mm}$ per year in 2010 , with an average of 5 years in year of $2,723 \mathrm{~mm}$ per year. There are 2 (two) big river which become heart of big enough water requirement to be utilized especially for irrigation that is Cimanuk River and Cilutung River. In 2011 the air temperature in Majalengka Regency ranged from 26.8 to 29.3 degrees celcius. Maximum air temperature occurred in October of $35.3^{\circ} \mathrm{C}$, while the minimum air temperature occurred in August with a temperature of $22.7^{\circ} \mathrm{C}$. Average wind speeds ranged from 3 to 5 knots per hour with a top speed in March of 28 knots per hour, making the Majalengka Regency nicknamed the City of Wind.

\section{$2.2 \quad$ Supply sources}

The water supply system in Majalengka Regency consists of piping systems and non-piped systems. Piping systems are managed by municipal waterworks while non-piped systems are managed by the community. The areas that have been served by water piped systems are urban areas mostly located in Majalengka Central District, while nonpiped areas (community-managed) are located in
Majalengka Regency in the North and South. For the South Majalengka Regency generally do not face problems in the fulfillment of their water supply because the water source is available by utilizing the water springs. However, the fulfillment of water demanddemands in the northern region of Majalengka Regency is still derived from ground water. The quantity of ground water is not sufficient and the quality of water is also not good because it contains lime.

There are many water sources utilized by municipal waterworks Majalengka district. Water source utilized by municipal waterworks Majalengka district are Cilongkrang Springs, Cisurian Springs, Cipadung Springs, Cihaneut Springs, Cibulakan Spring, Citamba Springs, Cigowong Springs, Colom Springs, Cilutung River, Cimanuk River, and Jatigede Reservoir. Based on Busines Plan municipal waterworks Majalengka District, from 26 Subdistricts in Majalengka new district 11 Subdistricts that have been served with the number of 67 villages. In addition, Majalengka district has some other potential surface water in the form of lake located in Cipadung, Umbrella, Sangiang, and Talagaherang villages. Groundwater, based on existing potential conditions, in general the Northern and Central Territories of Majalengka district have the potential of good quality ground water.

\subsection{Previous Study}

Several studies have been done to analyze the water balance in the study area. The total water demand has been calculated in the previous study, the total water requirement is the amount of domestic water demand covering the needs of airport and residential activities and industrial water requirements projected as an integrated industrial location. The estimated total annual requirement is presented in the Table 1.

\begin{tabular}{|c|c|c|c|c|c|c|}
\hline \multirow{2}{*}{ No. } & \multirow{2}{*}{$\begin{array}{l}\text { Types of } \\
\text { Needs }\end{array}$} & \multicolumn{5}{|c|}{ Projected water demand $(\mathrm{m} 3 / \mathrm{s})$} \\
\hline & & 2007 & 2010 & 2025 & 2030 & 2040 \\
\hline 1 & Domestic & 0.1038 & 0.0855 & 0.3306 & 0.3950 & 0.7831 \\
\hline 2 & Industry & 0.0000 & 0.0213 & 0.1150 & 0.1400 & 0.3211 \\
\hline 3 & Maintena & 0.0052 & 0.0150 & 0.0223 & 0.0268 & 0.0552 \\
\hline 4 & Irigation & 1.0747 & 1.1024 & 1.2516 & 1.3660 & 1.4210 \\
\hline & Total & 1.1837 & 1.2242 & 1.7195 & 1.9278 & 2.5804 \\
\hline
\end{tabular}

Table 1. Total water demand from previous study

Source: Final Report of Feasibility Study of Cipanasaat Reservoir Construction (PT. Sarana Bhuana Raya, 2006)

The result shows the maximum monthly average discharge occurs in January with $4.021 \mathrm{~m}^{3} / \mathrm{s}$ and the minimum in September with $0.144 \mathrm{~m}^{3} / \mathrm{s}$, with the average per year is $1.771 \mathrm{~m}^{3} / \mathrm{s}$. The water availability can be determined as the dependable flow (80\%). Maximum dependable flow occurs in February with value of 3.505 $\mathrm{m}^{3} / \mathrm{s}$ and the minimum is in October with value of 0.106 $\mathrm{m}^{3} / \mathrm{s}$. Water Balance in the Cipanasaat watershed is reviewed for local hydrological conditions with respect to the inflow of each tributary and water requirements along the river channel, water balance diagram for water availibility and water demand from 2007 to 2040 shown in Figure 2. Based on the water availability analysis, the 
monthly dependable flow is range between 0.106-3.382 $\mathrm{m}^{3} / \mathrm{s}$, with the maximum occurring in January and the minimum occurring in October. While the water requirement of the Sub-watershed currently in 2007 is $0.109 \mathrm{~m}^{3} / \mathrm{s}$, short term in 2010 is $0.122 \mathrm{~m}^{3} / \mathrm{s}$, medium term in 2020 is $0.468 \mathrm{~m}^{3} / \mathrm{s}$, and long term in 2040 is $1.156 \mathrm{~m}^{3} / \mathrm{s}$. The results of the water development analysis show that for the water supply from Cipanasaat River in the medium and long term will experience deficiency especially in the dry season.

\section{Methodology}

Concept of aerocity development is an area in which there are various activities support each other with the activities

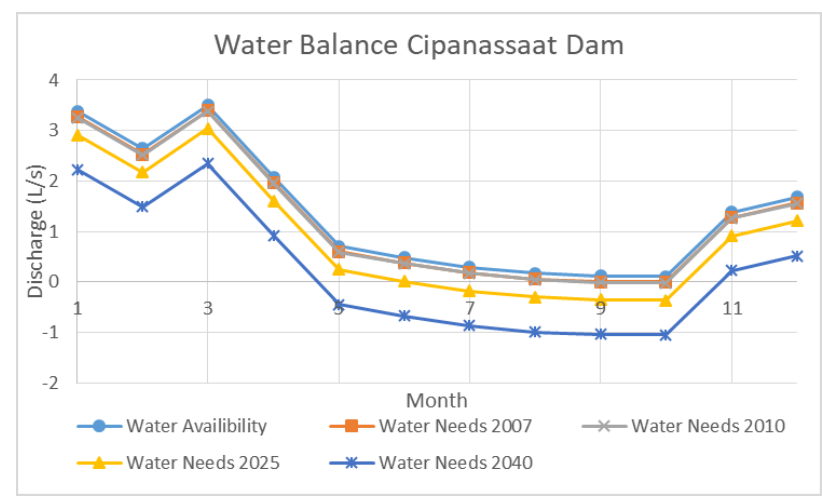

Fig. 2. Water balance

Source: Final Report of Feasibility Study of Cipanasaat

Reservoir Construction (PT. Sarana Bhuana Raya, 2006) of the airport. There are three main activities on aerocity design namely core aeronautical activities, airport related activities and airport oriented activities. Based on this concept, Kertajati aerocity has two schemes of airport activity type of airport there are activities within the aerocity and outside the aerocity. Therefore the analysis in this study was conducted on both areas within the aerocity and outside.

To allow water allocation, we need to calculate the water demand and supply on the location study. This study only take into account the quantitative factors, therefore it is assumed that all the water resources from three rivers have the same quality dan able to use as a water resource.

There are three stages of analysis used in this research; projection of water demand, water requirement, and water distribution. Projected water demand are intended to serve domestic facilities, educational facilities, health, offices, tourism, handling and industry. To meet the water demand of each activity calculated based on predictions every year until 2040. Total water demand is the amount of domestic water demand which covering the needs of airport and residential activities and industrial water demand projected as an integrated industrial location.

Water availability will be analyzed using F.J Mock method. F.J. Mock (1973) [3] proposed a monthly water balance simulation model for the drainage region in Indonesia, known as the Mock flow simulation. This model is specifically used for rivers in Indonesia
(Bappenas, 2006). The Mock method refers to the water balance in which the total water volume in the earth is fixed, only its circulation and distribution varies. Mock takes into account the volume of incoming (rain), out and stored water in the soil (infiltration, percolation and evapotranspiration).

Water resources network of Kertajati Aerocity will use piping system, so analysis of capacity and water allocation is required to support the plan.

The software that supports the analysis is Water Evaluation and Planning System (WEAP). The WEAP algorithm is implemented as a series of linear programming (LP) problems, iterated over demand and supply priorities. The algorithm is documented in Yates, Sieber, et al. (2005) [6]. WEAP has been used in several water related researches across the world, for example to determine the impact of a number of possible Development scenarios in Lake Tana Catchment, Ethiopia (Alemayehu et al. 2010) [7]. It was also used to evaluate Ethiopia's policy of large dam construction in the Blue Nile River basin by simulating the impact of climate change scenario on the performance of existing and planned hydropower and irrigation schemes (McCartney and Girma 2012) [8].

WEAP operates with the basic principle of water balance and can be applied to municipal and agricultural systems, single river basins or complex watershed systems. WEAP simulates various natural and engineering components of this system, including rainfall runoff, relative steady streams, and groundwater infiltration from rainfall; Sectoral demand analysis; Water conservation; Water policies and allocation priorities, reservoir operations; Generation of hydropower; Tracking pollution and water quality; Kerentana assessment; And ecosystem requirements.

\section{Results and discussion}

\subsection{Projected water demand}

The three sub districts of the study area have function as Kertajati Local Activity Center with service function as commercial and service area, integrated industrial area, BIJB area, urban development "aerocity", and agriculture. In this research, the total water demand of those three subdistricts is analyzed, includes water demand of domestic facilities, education facilities, health facilities, office facilities, tourism facilities, trade and service facilities, and industrial estates.

Projection of water is done based on Local Regulation and Spatial Planning of Majalengka district. Water demand is calculated by considering the population growth rate of $4 \%$ and water requirement 120 $\mathrm{L} /$ day/person. The ratio of the population of Kertajadi district and the number of worker in each facilities and water requirement for each facilities shown in Table 2. 
Table 2. Water demand for each facilities

\begin{tabular}{|c|c|c|c|c|c|c|}
\hline \multirow{3}{*}{ Facilities } & \multicolumn{6}{|c|}{ District } \\
\hline & \multicolumn{2}{|c|}{ Kertajati } & \multicolumn{2}{|c|}{ Jatitujuh } & \multicolumn{2}{|c|}{ Ligung } \\
\hline & Ratio/Area & \begin{tabular}{|c} 
Water Needs \\
$(\mathrm{L} / \mathrm{d} / \mathrm{p})$
\end{tabular} & Ratio/Area & \begin{tabular}{|c} 
Water Needs \\
$(\mathrm{L} / \mathrm{d} / \mathrm{p})$
\end{tabular} & Ratio/Area & $\begin{array}{c}\text { Water Needs } \\
(\mathrm{L} / \mathrm{d} / \mathrm{p})\end{array}$ \\
\hline Education & $10.09 \%$ & 10 & $25.23 \%$ & 10 & $22.93 \%$ & 10 \\
\hline Health & $7.94 \%$ & 200 & $7.94 \%$ & 200 & $10.64 \%$ & 200 \\
\hline Office & $6.17 \%$ & 10 & $13.20 \%$ & 10 & $17.80 \%$ & 10 \\
\hline Industry & $20 \%$ & 60 & $20 \%$ & 60 & $20 \%$ & 60 \\
\hline Tourism & $74.46 \mathrm{Ha}$ & 0.3 & $770.61 \mathrm{Ha}$ & 0.3 & $428.3 \mathrm{Ha}$ & 0.3 \\
\hline $\begin{array}{c}\text { Trade and } \\
\text { Service }\end{array}$ & $1504.1 \mathrm{Ha}$ & 12,000 & $381.82 \mathrm{Ha}$ & 12,000 & $177.41 \mathrm{Ha}$ & 12,000 \\
\hline
\end{tabular}

Source: Analysis Result

The total demand of three district can be seen from recent years (2015) untill projected years in 2040 in Figure 3. At 2040 total water demand will reach 1,450.60 $\mathrm{L} / \mathrm{s}$.

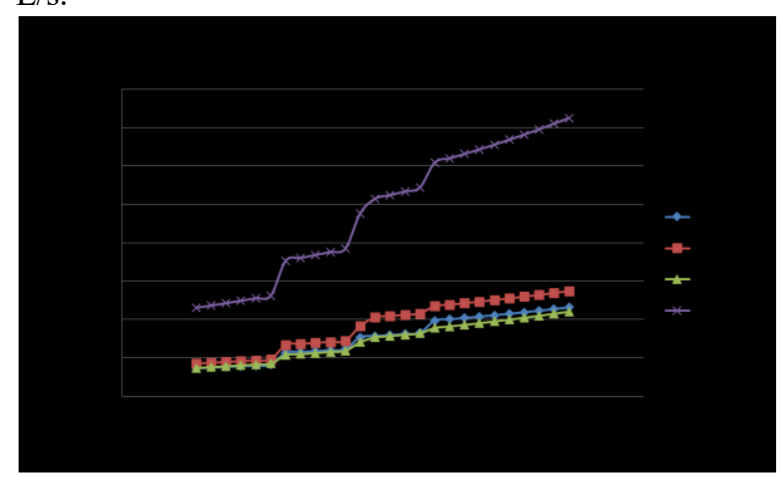

Fig. 3. Total water demand Source: Analysis Result

\subsection{Water avaibility}

From the survey results, Cibeureum Lake, Nyesel Lake, Anggrarahan Lake, Tarisi Lake, Belik Lake, Jawura Lake, Cimaneuh Lake, Citamiang Lake, Cicabe Lake, Telik Lake can only be used during the rainy season because the water source are from rain water. So the analysis of water availability is only done in 3 points, namely Cimanuk Tomo River, Cimanuk-Monjot River, and Cilitung-Dam Kamun River. Water availibility for each river shown in Figure 4.

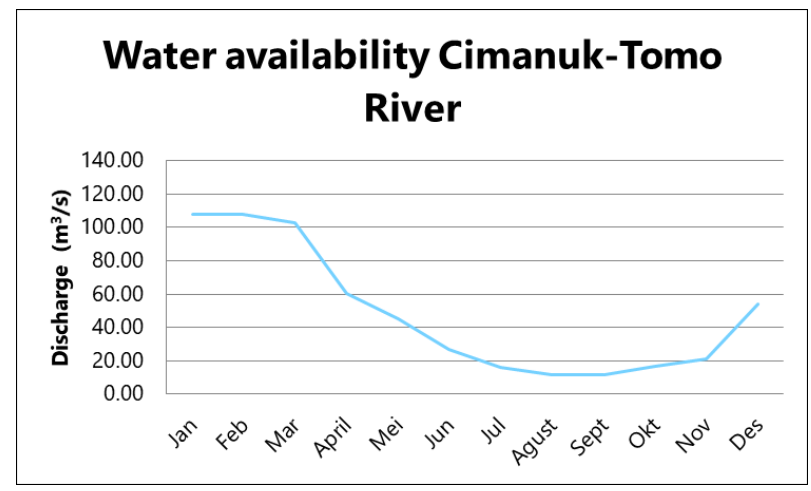

(a)

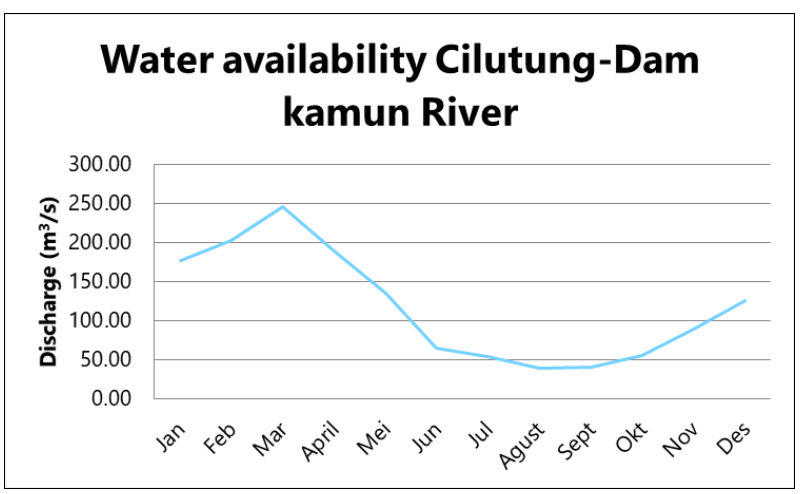

(b)

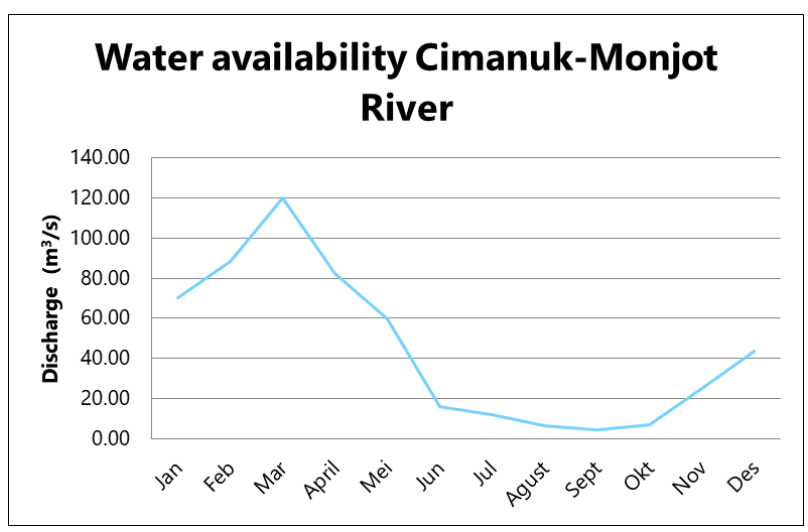

(c)

Fig. 4. Water avaibility Source: Analysis Result

\subsection{Water allocation}

In this study, water balance analysis of Kertajati, Jatitujuh, and Ligung districts is conducted. GIS-based data in the form of river networks, lake points, and water use allocation can be seen in the Figure 5. The water allocation for each district is classified into seven in accordance with the previous analysis. Water collection for each class has been set previously. Each allocation is given the value of percentage amount of water consumed. Unconsumed water will be returned to the river. The classification of water allocation and percentage of water consumed, and water retrieval can be seen in the Table 3 .

The water source used in this water allocation model is surface water taken from the Cimanuk-Monjot River. This is done with the following considerations:

- The location of Cilutung River is on the different side with the study location and the river empties into Cimanuk River, so it will be more efficient if water retrieval done in main river (Cimanuk River) compared to making channel from Cilutung River to study location.

- The result of water availability analysis in CimanukTomo River is greater than the availability of water in the Cimanuk-Monjot River, whereas the Cimanuk Monjot River is located downstream of the Cimanuk River and Cilutung River catchments. So it is assumed there are water retrieval in the CimanukTomo River range and Cimanuk-Monjot River. 
Table 3 Water calssification and

\begin{tabular}{|c|c|c|c|}
\hline Demand Site & 2015 & Scale & Unit \\
\hline JATITUJUH Industri & 70 & Percent & \\
\hline JATITUJUH Kesehatan & 40 & Percent & \\
\hline JATITUJUH Pariwisata & 30 & Percent & \\
\hline \begin{tabular}{|l|} 
JATITUJUH Pendidikan \\
\end{tabular} & 20 & Percent & \\
\hline JATITUJUH Perdagangan & 30 & Percent & \\
\hline \begin{tabular}{|l} 
JATITUJUH Perkantoran \\
\end{tabular} & 20 & Percent & \\
\hline JATITUJUH Perumahan & 50 & Percent & \\
\hline KERTANATII Industri & 70 & Percent & \\
\hline KERTAJATI Kesehatan & 40 & Percent & \\
\hline KERTAJAATI Pariwisata & 30 & Percent & \\
\hline KERTAJATI Pendidikan & 20 & Percent & \\
\hline KERTAJAATI Perdagangan & 30 & Percent & \\
\hline KERTAJAATI Perkantoran & 20 & Percent & \\
\hline KERTAJATI Perumahan & 50 & Percent & \\
\hline LIGUNG Industri & 70 & Percent & \\
\hline LIGUNG Kesehatan & 40 & Percent & \\
\hline LIGUNG Pariwisata & 30 & Percent & \\
\hline LIGUNG Pendidikan & 20 & Percent & \\
\hline LIGUNG Perdagangan & 30 & Percent & \\
\hline LIGUNG Perkantoran & 20 & Percent & \\
\hline LIGUNG Perumahan & 50 & Percent & \\
\hline
\end{tabular}

- However, the availability of Cimanuk River water must be rectified after the Jatigede Reservoir operates because the availability of Cimanuk River water will depend on the water that the reservoir estimates.

- In addition, although the location of the CimanukMonjot River more downstream, but closer to the location of the study.

Water demand projection from 2015 to 2040 can be seen in Figure 6. Based on the results of analysis using WEAP, Cimanuk River can meet the water demand in these three sub-districts until 2040.

\section{Conclusions}

From the results of studies it can be taken some conclusions as follows:

- Water retrieval from Cilutung River to meet the water demand in Kertajati, Jatijutuh, and Ligung district is less effective because the location of the

\begin{tabular}{|c|c|c|c|c|}
\hline Demand Site & 2015 & Scale & Unit & \\
\hline JATITUJUH Industi & 21900 & & $\mathrm{~L}$ & /person \\
\hline JATITUJUH Kesehatan & 73000 & & L & /person \\
\hline JATITUJUH Pariwisata & 9460800 & & L & Thectare \\
\hline JATITUJUH Pendidikan & 3650 & & L & /person \\
\hline \begin{tabular}{|l|} 
JATITUJUH Perdagangan \\
\end{tabular} & 4380000 & & L & Thectare \\
\hline $\begin{array}{l}\text { JATITUJUH Perkantoran } \\
\end{array}$ & 3650 & & L & /person \\
\hline \begin{tabular}{|l|} 
JATITUJUH Perumahan \\
\end{tabular} & 43800 & & L & /person \\
\hline KERTAJAATI Industri & 21900 & & L & /person \\
\hline KERTAJATI Kesehatan & 73000 & & L & /person \\
\hline KERTANATI Pariwisata & 9460800 & & L & hectare \\
\hline KERTAJATII Pendidikan & 3650 & & L & /person \\
\hline KERTAJAATI Perdagangan & 4380000 & & L & hectare \\
\hline KERTAJJATI Perkantoran & 3650 & & L & /person \\
\hline KERTAJATI Perumahan & 43800 & & L & /person \\
\hline LIGUNG Industri & 21900 & & L & iperson \\
\hline LIGUNG Kesehatan & 73000 & & L & /person \\
\hline LIGUNG Pariwisata & 9460800 & & L & Thectare \\
\hline LIGUNG Pendidikan & 3650 & & L & /person \\
\hline LIGUNG Perdagangan & 4380000 & & L & Thectare \\
\hline LIGUNG Perkantoran & 3650 & & L & /person \\
\hline LIGUNG Perumahan & 43800 & & L & /person \\
\hline
\end{tabular}

river is on the different side of the three districts and empties into Cimanuk River. However, the river can be an option but the water availability record in the river must be validated because the existing data is not in accordance with the conditions in the field.

- Water sources that can be used to meet water demand in Kertajati, Jatijutuh, and Ligung district are Cimanuk River (Cimanuk-Monjot). However, the availability of water in Cimanuk River must be corrected after the Jatigede Reservoir operates because the availability of water in the river will be greatly influenced by the flow of water that flowed reservoir

- There is no water source in Kertajati, Jatitujuh and Ligung sub-districts that can meet the water demand of the three sub-districts.

- In this study has identified potential water resources in other areas that can be used to meet water demand in Kertajati, Jatitujuh and Ligung districts.

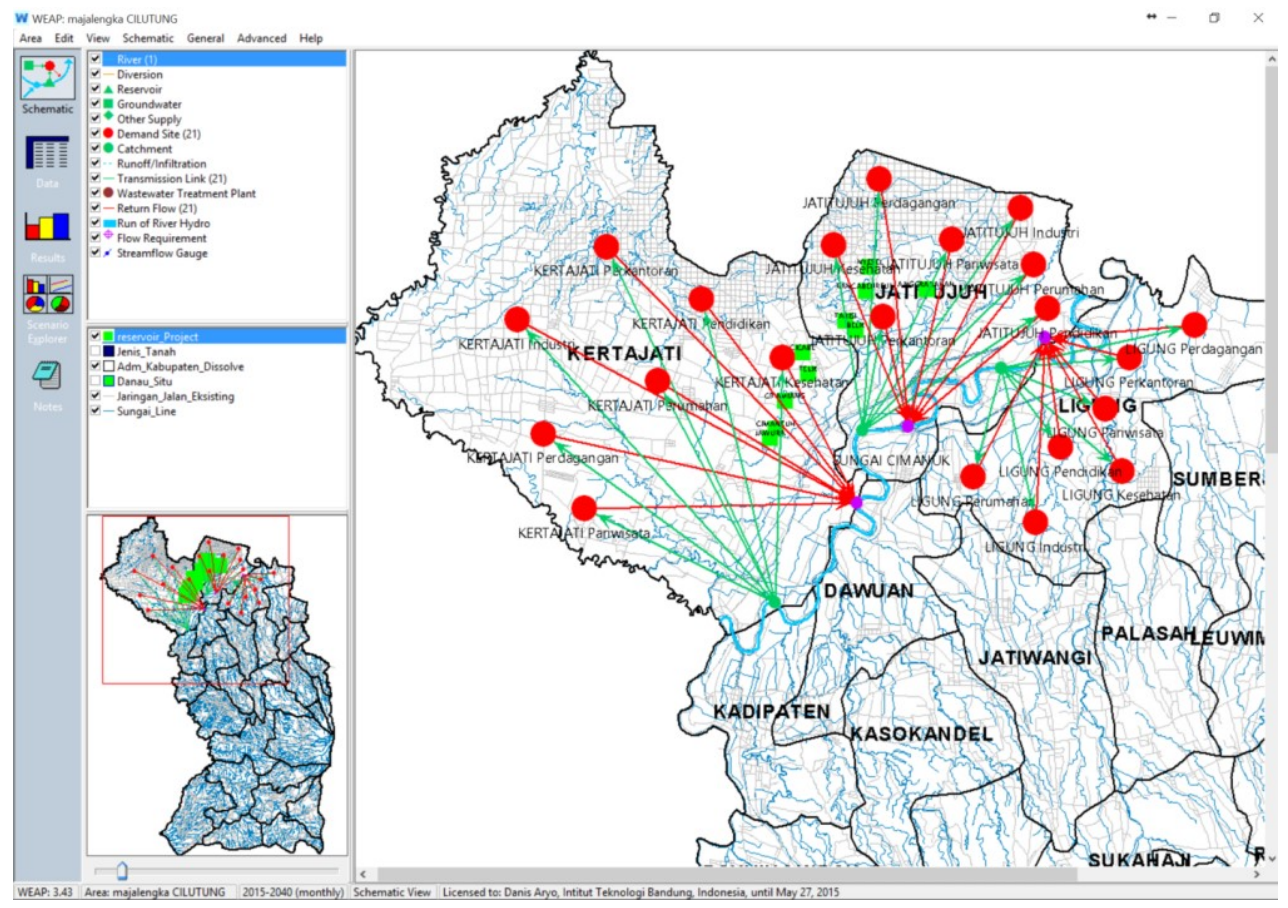

Fig. 5. WEAP Scheme 


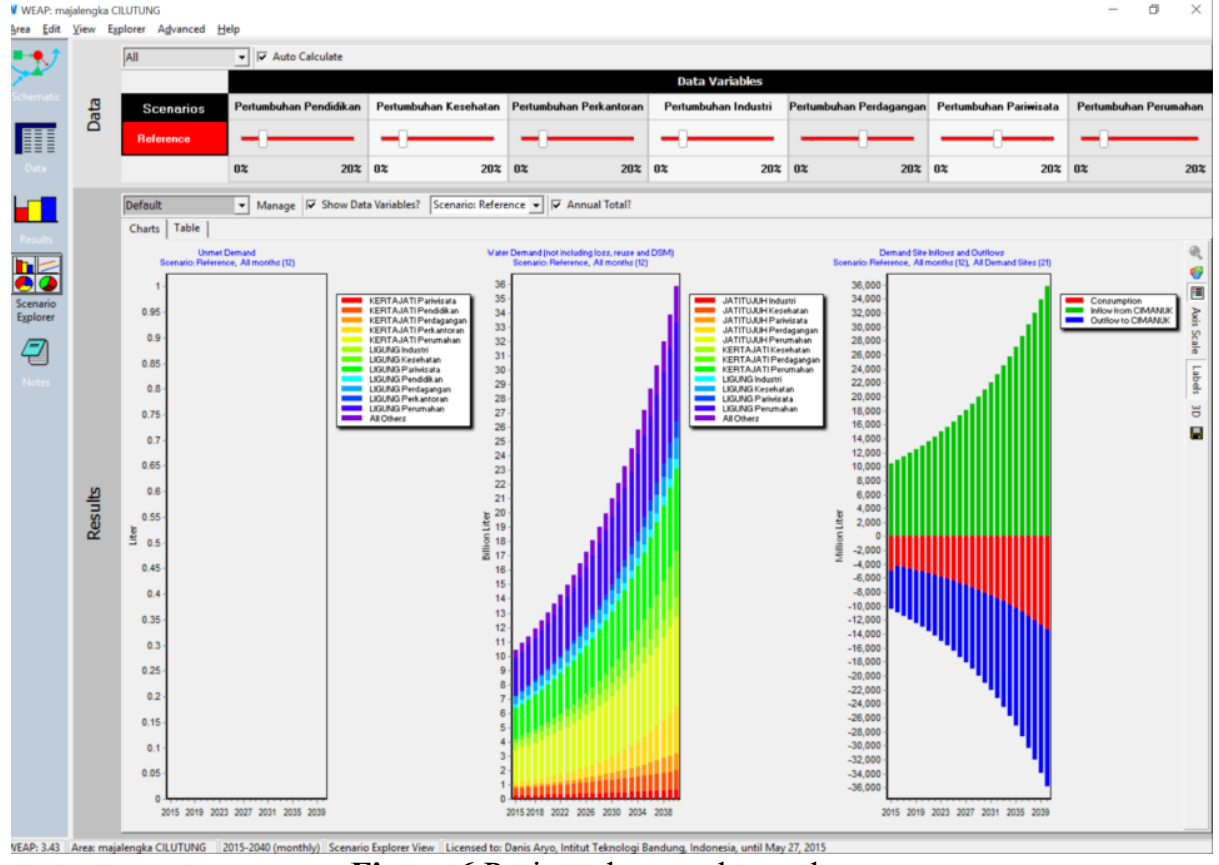

Figure 6 Projected water demand

- Based on the data obtained, the water demand in these three sub-districts can still be met up to 2040 by relying on the existing river flow.

- Required data clarification, especially river flow measurement data and other water source potentials to support the results of studies that have been done.

\section{References}

1. LPPM ITB, Final Report Study of Raw Water Potential for BIJB Area and Kertajati (2015)

2. PT. Sarana Bhuana Raya, Final Report of Feasibility Study of Cipanasaat Reservoir Construction (2006)

3. F.J. Mock, Water Availibity Appraisal (1973)

4. T.B. Adgolign et al, WEAP modeling of surface water resources allocation in Didessa Sub-Basin, West Ethiopia. Springer Int. Publishing Switzerland (2015)

5. A. Alfarra et al, Modeling Water Supply and Demand for Effective Water Management Allocation in the Jordan Valley. Journal of Agricultural and Aplications (JASA) (2012)

6. Yates D, Sieber J, Purkey D, Lee, WEAP21-a demand-, priority-, and preference-driven water planning model-part 1: model characterisitics. Int Water Res Assoc 30(4): 487-500 (2005)

7. T. Alemayehu, M. McCartney, S. Kebede, The water resource implications of planned development in the Lake Tana catchment. Ethiopia Ecohydrol Hydrol 10(2-4):211-222 (2010)

8. M.P. McCartney, M.M Girma, Evaluating the downstream implications of planned water resource development in the Ethiopian portion of the Blue Nile River. Water Int 37(4):362-379 (2012)

9. Obahoundje et al, Land Use and Land Covers Changes under Climater Undercertainty: Modelling the Impacts on Hydropower Production in Western Africa, MDPI (2017)

10. PT. Bandarudara International Jawa Barat, About PT BIJB, http://bijb.co.id/en/sejarah/ (30 July 2017). 